vol.5, Special Issue - 2018

\title{
OLIVE OIL ON NIPPLE TRAUMA AMONG LACTATING
} MOTHERS

\author{
Haylaa Nageeb ${ }^{1}$, Eman A. Fadel ${ }^{2}$, Nahed Fikry Hassan ${ }^{3}$ \\ ${ }^{I}$ MSC. Faculty of Nursing, Port-Said University, Egypt. \\ ${ }^{2}$ Lecturer of Woman's Health and Midwifery Nursing, Faculty of Nursing, Mansoura University, Egypt \\ ${ }^{3}$ Assistant Professor of Woman's Health and Midwifery Nursing, Faculty of Nursing, Mansoura University, Egypt \\ Corresponding Author E-mail:Haylaanageeb@gmail.com
}

\begin{abstract}
:
Nipple trauma is among the challenges that a lactating mother may face during early postpartum period. This study aimed to evaluate the effect of olive oil on nipple trauma among lactating mothers. A quasi-experimental study design was carried out at three private obstetric centers in Menyat El-Nasr City in Dakahlia governorate from January, 2017 to July, 2017. A purposive sample technique of 116 lactating mothers suffering from nipple trauma at their early puerperal period were chosen according to the inclusion criteria and assigned randomly into two equal groups of 58 lactating mothers; group one was the study group who rubbed olive oil on nipple after each feeding; group two was the control group who received routine pharmacological management for nipple trauma according to physician prescription. Two tools were used to collect the data; Structured Interview Schedule, and Nipple Trauma Score. Results of the present study showed that, majority of lactating mothers who used olive oil had faster recovery of nipple trauma post intervention more than control group with statistical significant differences. Conclusion: Olive oil is a safe natural method that can be used to treat nipple trauma among lactating mothers.
\end{abstract}

Keywords: Lactation, Nipple trauma, Olive oil.

\section{Introduction:}

Early puerperium period is the time of supreme change, and puerperal mothers usually describe the first few weeks of breastfeeding as hard time due to arise of many unexpected breastfeeding problems $^{(1)}$. The first predictor for increase the chance of exclusive breast feeding is the absence of lactation problems ${ }^{(2)}$. One of these problems that may contribute to decrease the rate of exclusive breastfeeding is nipple trauma ${ }^{(3)}$.

Nipple trauma is an alteration in the normal anatomy of the nipple skin with the presence of a primary lesion as appear as a change in the color and thickness of the nipple skin ${ }^{(4)}$. Other changes which may appear including erythema, edema, ecchymosis, abrasions, fissures, cracks, and blisters on the nipple skin ${ }^{(5)}$.

The commonest time of occurrence of nipple trauma is usually between $3^{\text {rd }}$ and $7^{\text {th }}$ day postpartum and in some mothers may persist to $6^{\text {th }}$ weeks after delivery ${ }^{(6)}$. There are various methods had been used to either treat or prevent nipple trauma associated with breastfeeding such as exposure of the nipples to dry heat or ultraviolet light, or air-drying, teach the mother proper breastfeeding technique, application of ointments, tea bags, dressings, compresses, and expressed breast milk. Among all of the published trauma studies, no single treatment has been demonstrated to be effective ${ }^{(7)}$

Furthermore, others studies wondered about the effect of extra virgin olive oil (EVOO) on nipple trauma and showed that, EVOO was the most cheap, safe, and effective method for management of nipple trauma ${ }^{(8 \& 9)}$.

Olive is among the oldest known 
cultivated trees in the world and has been found in Egyptian tombs from 2,000 years before Christ (BC). Olive considered as an important source of oil. The uses of olive oil is found in many religions and cultures; in Islam, olive oil had blessing value and numerous uses, in Christianity and Judaism olive also carries a significant symbol of wisdom, and peace ${ }^{(10 \& 11)}$.

Olives, olive oil and olive trees were mentioned in the Holy Quran seven time in many places; six times explicitly (Surah at-Teen: ayah1, Abasa: 29, an- Nur: 35, an-Nahl: 11, al-An'am: 99, al-An'am: 141) and one time implicitly in (AlMu'minun: ayah 20) ${ }^{(10 \& 12)}$.

Muslims considered olive oil as an effective prophetic medicine since it was recommended by Prophet Muhammad (Peace and blessing of Allah be upon him) over 1400 years ago. Prophet Muhammad (Peace and blessing of Allah be upon him) advised his followers to eat or apply olive oil to their bodies. It was narrated by Ahmad and Al-Tirmithi that, Omar Ibn AlKhattab (Allah be pleased with him) reported that The Prophet Muhammad (Peace and blessing of Allah be upon him) said, eat olive oil and rub it on the skin, because it comes from a blessed tree ${ }^{(13)}$.

Extra virgin olive oil contains three major antioxidants substance which are: vitamin E, polyphenols, and phytosterols. Antioxidants, when topically applied to the skin help in protecting the skin from premature skin aging. While, vitamin $\mathrm{E}$ restores the skin smoothness so, EVOO has an anti-aging benefits (14). Additionally, other antioxidants substance was found in EVOO called Hydroxytyrosol which prevents free radical damage of the skin ${ }^{(15)}$.

Moreover, phenolic compounds which found in EVOO had been identified with other health benefits such as being antiviral, antibacterial, antimicrobial, and anti-inflammatory ${ }^{(16)}$.

\section{Significance of the study}

The occurrence rate of nipple trauma during breastfeeding varied from study to another, In recent study by Buck, Amir, Cullinane, and Donath, (2014) (17) estimated that, the occurrence rate of nipple trauma among primiparous women was $58 \%$ over a period of 8 weeks postpartum. While, in a very recent study by Dias, Vieira, and Vieira (2017) founded that, nipple trauma prevalence was from $26.7 \%$ to $52.75 \%$ and the incidence was from $16 \%$ to $100 \%$.

Nipple trauma as a complication associated with breast-feeding is considered amongst the most significant causes of cessation of breastfeeding and early weaning ${ }^{(19 \& 20)}$. It is a dream for each mother to achieve successful lactation to prevent and/or treat nipple problems and nipple trauma safely without any hazard to the baby from pharmacological agents and medications.

Although Egypt is one of the Mediterranean countries that cultivate olive trees and produce olive oil, and although all benefits of olive oil, there is no study done in Egypt related to uses of olive oil on nipple trauma yet. Hence, this study will be conducted to evaluate the effect of utilizing EVOO on nipple trauma among lactating mothers in early puerperium.

Study Aim

The present study aimed to evaluate the effect of utilizing extra virgin olive oil on nipple trauma among lactating mothers.

\section{Study Hypothesis}

Lactating mothers who utilize extra virgin olive oil exhibit faster recovery of nipple trauma than control group.

\author{
Subjects and Method \\ Study design \\ Quasi-experimental study design \\ was utilized in this study. \\ Study settings
}


OLIVE OIL ON NIPPLE TRAUMA AMONG etc...

The study was conducted at three private obstetric centers in Menyat El-Nasr City in Dakahlia Governorate which are; Egyptian center for Endoscopic Surgeries and Obstetrics and Gynecology, Doctor Samir's Center for Obstetrics and Gynecology, and El-Zahraa Center for Obstetrics and Gynecology.

\section{Study Subjects}

The study involved eligible lactating mothers in early puerperium who were attending to the previous mentioned settings and fulfilled the following inclusion criteria;

1. Lactating mothers affected by nipple trauma at early puerperal weeks.

2. Aged between 18-35 years.

3. Primipara or multipara.

4. Delivered normal or cesarean section.

5. Free from any obstetrical and medical disease.

6. Having a healthy full term single baby.

\section{Sample size calculation}

A purposive sample of 116 women was enrolled based on the data obtained from a previous study of $\boldsymbol{A} \boldsymbol{b} \boldsymbol{d}$ Elsalam et al. (2011) ${ }^{(18)}$, the sample size was calculated to be 58 for each group with the level of significance $=5 \%$, and Power $=80 \%$. Type of test $=$ two-sided the following formula is used: $\mathrm{n}=\left[2\left(\mathrm{Z}_{\alpha / 2}+\right.\right.$ $\left.\left.\mathrm{Z}_{\beta}\right)^{2} \times \mathrm{p}(1-\mathrm{p})\right] /(\mathrm{p} 1-\mathrm{p} 2)^{2}$. So, 116 lactating mothers who fulfilled the inclusion criteria were randomly allocated into two equal groups; 58 for each one. First group was the study group who asked to rub nipples with extra virgin olive oil after each feeding and the second group was the control group who received pharmacological management for nipple trauma according to physician prescription.

\section{Tools of data collection}

Two tools were used to collect the necessary data
Tool I: Structured Interview Schedule; it was developed by the researcher after reviewing the related literature and consisted of two parts; the first part describes the socio-demographic characteristics of lactating women, and the second part includes mother's obstetric history.

Tool II: Nipple Trauma Score (NTS); it was adopted from Abou-Dakn, Fluhr, Gensch \& Wöckel, (2011) ${ }^{(21)}$ to assess and score nipple trauma before and after intervention. The NTS is based on wound depth and the extent of tissue damage whereas; 0 indicate no visible skin changes; one indicate erythematic or edema or combination of both; two indicate superficial damage with or without scab formation of less than $25 \%$ of the nipple surface; three indicate superficial damage with or without scab formation of more than $25 \%$ of the nipple surface; four indicate partial-thickness wound with or without scab formation of less than $25 \%$ of the nipple surface and finally five indicate partial-thickness wound with or without scab formation of more than $25 \%$ of the nipple surface.

\section{Validity of the tools}

Content validity was tested by five experts in woman's health and midwifery nursing. The questionnaire was modified according to the expert's comments and recommendations by paraphrasing of some sentences and changing ordering and sequences of other sentences.

\section{Reliability}

The reliability of tools used in this study done using the Cronbach's alpha test. The degree of reliability by Cronbach's alpha test was $91.7 \%$ which mean being very reliable.

\section{Pilot study}

Pilot study was conducted on $10 \%$ of the total sample which equal 12 lactating mothers; distributed into two groups to be six mothers for each one. The 
pilot study sample was excluded from the main study sample.

\section{Field work}

Data was collected four days per week (Saturday, Sunday, Tuesday and Wednesday) over a period of seven months from the beginning of January, 2017 to the end of July, 2017. The work was conducted through four phases (assessment, planning, implementation and evaluation).

\section{Assessment phase:}

The purpose of the study was explained to each mother, who agreed to participate in the study, then a written consent was obtained from them and they were assured about confidentiality and privacy. Each participant was individually interviewed in the follow up unit in order to collect the socio demographic and clinical data, and also assessment grade of nipple trauma by researcher and doctor.

\section{Planning phase:}

The olive oil was bought from ElArish city and analyzed for its some chemical characteristics at the laboratory of Natural Oil Extraction Unit in National Research Centre, Cairo, Egypt. According to the results obtained from national research center, the olive oil that was used in this study has acidity $0.4 \%$ and peroxide value $14.5 \mathrm{meq} . / \mathrm{kg}$ to be identical for quality criteria published by international olive council, 2015 which states that, the free acidity of EVOO must be $\leq 0.8 \% \mathrm{~m} / \mathrm{m}$ expressed in oleic acid and Peroxide value must be $\leq 20$ in mill eq., peroxide oxygen per kg/oil $\left(\right.$ IOC, 2015) ${ }^{(22)}$. So, the olive oil used in this study was classified as extra virgin olive oil.

Then a suitable amount of olive oil about $(100 \mathrm{ml})$ was packaged in small brown glass bottles of $120 \mathrm{ml}$.

\section{Implementation phase:}

Started from the first day of enrollment in which; Group I (study group) asked to wash nipples after each breastfeeding and rub the affected nipples and areola with few drops of EVOO after each feeding then expose nipples to air-dry from day of enrollment to the fourteenth day after enrollment while Group II; (control group) received pharmacological management for nipple trauma according to physician prescription.

\section{Evaluation phase:}

After seventh day and fourteenth day of the intervention the mothers were examined within 10 minutes by the researcher and the physician to evaluate improvement or impairment of the grade of nipple trauma.

\section{Strength of the Study:}

All centers' physician and health team workers were welcoming and cooperative.

\section{Limitation of the Study:}

Incomplete follow up and drop out of 6 cases for control group and 2 cases for EVOO group because of irregular follow up so; the researcher replaced them by others.

\section{Statistical analysis:}

All statistical analyses were performed using SPSS for windows version 20.0 (SPSS, Chicago, IL). Data were tested for normality of distribution prior to any calculations. All continuous data were expressed in mean \pm standard deviation and categorical data were expressed in number and percentage. The comparisons among the groups were determined using one-way ANOVA test for variables with continuous data and chisquare test for comparison among groups with categorical data. The correlations were tested using the correlation coefficient test. Statistical significance was set at $\mathrm{p}<0.05$.

\section{Ethical Consideration:}

Written approvals were obtained from the director of each centre included in the study. The researcher explained the purpose of the study to the mothers and a written consent were obtained and they assured about confidentiality and 
OLIVE OIL ON NIPPLE TRAUMA AMONG etc...

autonomist.

\section{Results:}

Table (1) shows that, more than one third of lactating mothers aged between 21-25years, and the majority of lactating mothers $(70.7 \%$, and $82.8 \%)$ were form rural area in EVOO, and control groups respectively.

Concerning to level of education, it was found that more than half $(51.7 \%)$ of EVOO group and near to half $(48.3 \%)$ of control group had secondary educational level. Additionally, the majority of mothers $(82.8 \%$, and $81.0 \%)$ were housewives in EVOO and control groups respectively.

Regarding reproductive history; more than half of lactating mothers in both groups $(67.2 \%$, and $58.6 \%)$ were primipara, more than two thirds of lactating mothers $(79.3 \%$, and $81.0 \%)$ were delivered by caesarian section and more than half $(50.0 \%$, and $60.3 \%)$ of lactating mothers had female newborn in EVOO and control groups respectively.

Table (2) represents the grade of nipple trauma among lactating mothers pre and post intervention in EVOO group. It is obvious from the table that, there is a highly statistically significant improvement on the trauma grade between pre and post intervention on $7^{\text {th }}$ and $14^{\text {th }}$ days from using EVOO ( $\mathrm{P}$ value $<0.001$ ).

Additionally, table (3), illustrates that, in routine care group the nipple trauma grade was improved on $7^{\text {th }}$ and $14^{\text {th }}$ days with a highly statistically significant difference ( $\mathrm{P}$ value <0.001).

Table (4) reveals that, less than half of EVOO and control groups $(46.6 \%$ and $48.4 \%$ ) respectively had superficial damage of nipple less than $25 \%$ on the first day of enrolment (pre-intervention) with no statistical significant differences among two groups $(\mathrm{P}>0.05)$ (figure 1).

As well, slightly more than half $(51.7 \%)$ of EVOO group and slightly less than one third $(31.0 \%)$ of control group had healthy skin (no skin change) on the seventh day post intervention with statistical significant differences $(\mathrm{P}<$ 0.05).

Furthermore, the majority $(89.7 \%)$ of EVOO group and slightly less than two thirds $(63.8 \%)$ of control group had healthy skin which mean no skin changes on the fourteenth day post intervention with statistical significant differences $(\mathrm{P}=$ 0.004) (figure 2). 
Haylaa Nageeb et. al.

Table 1. Frequency distribution of general characteristics and reproductive history of the lactating mothers $(\mathrm{N}=174)$

\begin{tabular}{|c|c|c|c|c|c|c|}
\hline \multirow[t]{2}{*}{ General characteristics } & \multicolumn{2}{|c|}{$\begin{array}{c}\text { EVOO group } \\
(n=58)\end{array}$} & \multicolumn{2}{|c|}{$\begin{array}{c}\text { Control group } \\
(n=58)\end{array}$} & \multicolumn{2}{|c|}{$\begin{array}{c}\text { Chi square } \\
\text { test }\end{array}$} \\
\hline & No. & $\%$ & No. & $\%$ & $\mathbf{X}^{2}$ & $\mathbf{P}$ \\
\hline \multicolumn{7}{|l|}{ Age } \\
\hline$\leq 20$ years & 18 & 31.0 & 13 & 22.4 & & \\
\hline $21-25$ years & 21 & 36.2 & 20 & 34.5 & & \\
\hline $26-30$ years & 14 & 24.1 & 17 & 29.3 & & \\
\hline$\geq 31$ years & 5 & 8.6 & 8 & 13.8 & 1.813 & 0.612 \\
\hline Mean \pm SD & \multicolumn{2}{|c|}{$23.5 \pm 4.3$} & \multicolumn{2}{|c|}{$24.9 \pm 4.6$} & $1.693^{*}$ & 0.093 \\
\hline \multicolumn{7}{|l|}{ Residence } \\
\hline Rural & 41 & 70.7 & 48 & 82.8 & & \\
\hline Urban & 17 & 29.3 & 10 & 17.2 & 2.365 & 0.124 \\
\hline \multicolumn{7}{|l|}{ Marital status } \\
\hline Married & 58 & 100.0 & 58 & 100.0 & NA & NA \\
\hline \multicolumn{7}{|l|}{ Educational status } \\
\hline Basic & 5 & 8.6 & 8 & 13.8 & & \\
\hline Intermediate & 30 & 51.7 & 28 & 48.3 & & \\
\hline Higher & 23 & 39.7 & 22 & 37.9 & 0.783 & 0.676 \\
\hline \multicolumn{7}{|l|}{ Occupational status } \\
\hline Working & 10 & 17.2 & 11 & 19.0 & & \\
\hline Not working & 48 & 82.8 & 47 & 81.0 & 0.058 & 0.810 \\
\hline \multicolumn{7}{|l|}{ Parity } \\
\hline Primi & 39 & 67.2 & 34 & 58.6 & & \\
\hline Multi & 19 & 32.8 & 24 & 41.4 & 0.924 & 0.336 \\
\hline \multicolumn{7}{|l|}{ Mode of last delivery } \\
\hline Vaginal & 2 & 3.4 & 0 & 0.0 & & \\
\hline $\begin{array}{l}\text { Vaginal with } \\
\text { episiotomy }\end{array}$ & 10 & 17.2 & 11 & 19.0 & & \\
\hline Caesarean section & 46 & 79.3 & 47 & 81.0 & 2.058 & 0.357 \\
\hline \multicolumn{7}{|l|}{ Sex of newborn } \\
\hline Male & 29 & 50.0 & 23 & 39.7 & & \\
\hline Female & 29 & 50.0 & 35 & 60.3 & 1.255 & 0.263 \\
\hline
\end{tabular}

*t value, Student's t test 
OLIVE OIL ON NIPPLE TRAUMA AMONG etc...

\begin{tabular}{|c|c|c|c|c|c|c|c|c|}
\hline \multirow[t]{2}{*}{$\begin{array}{c}\text { Grade of nipple } \\
\text { trauma }\end{array}$} & \multicolumn{2}{|c|}{$\begin{array}{l}1^{\text {st }} \text { day } \\
(n=58)\end{array}$} & \multicolumn{2}{|c|}{$\begin{array}{c}7^{\text {th }} \text { day } \\
(n=58)\end{array}$} & \multicolumn{2}{|c|}{$\begin{array}{c}14^{\text {th }} \text { day } \\
(n=58)\end{array}$} & \multicolumn{2}{|c|}{ Chi square test } \\
\hline & No. & $\%$ & No. & $\%$ & No. & $\%$ & $\mathbf{X}^{2}$ & $\mathbf{P}$ \\
\hline No skin change & 0 & 0.0 & 30 & 51.7 & 52 & 89.7 & & \\
\hline $\begin{array}{l}\text { Erythema and/or } \\
\text { edema }\end{array}$ & 9 & 15.5 & 17 & 29.3 & 5 & 8.6 & & \\
\hline $\begin{array}{l}\text { Superficial damage } \\
<25 \%\end{array}$ & 27 & 46.6 & 7 & 12.1 & 0 & 0.0 & & \\
\hline $\begin{array}{l}\text { Superficial damage } \\
25 \%\end{array}$ & 22 & 37.9 & 4 & 6.9 & 1 & 1.7 & 120.393 & $<0.001^{* *}$ \\
\hline
\end{tabular}

*Statistically significant at $p \leq 0.05$

Table 3. Comparison of the nipple damage score of the lactating mothers in the control group ( $\mathrm{N}=58$ )

\begin{tabular}{|c|c|c|c|c|c|c|c|c|}
\hline \multirow{2}{*}{$\begin{array}{l}\text { Grade of nipple } \\
\text { trauma }\end{array}$} & \multicolumn{2}{|c|}{$\begin{array}{l}1^{\text {st }} \text { day } \\
(n=58)\end{array}$} & \multicolumn{2}{|c|}{$\begin{array}{l}7^{\text {th }} \text { day } \\
(n=58)\end{array}$} & \multicolumn{2}{|c|}{$\begin{array}{c}14^{\text {th }} \text { day } \\
(n=58)\end{array}$} & \multicolumn{2}{|c|}{ Chi square test } \\
\hline & No. & $\%$ & No. & $\%$ & No. & $\%$ & $\mathbf{X}^{2}$ & $\mathbf{P}$ \\
\hline No skin change & 0 & 0.0 & 18 & 31.0 & 37 & 63.8 & & \\
\hline Erythema and/or edema & 10 & 17.2 & 16 & 27.6 & 9 & 15.5 & & \\
\hline Superficial damage $<25 \%$ & 28 & 48.3 & 14 & 24.1 & 7 & 12.1 & & \\
\hline Superficial damage $>25 \%$ & 20 & 34.5 & 10 & 17.2 & 5 & 8.6 & 63.803 & $<0.001^{* * *}$ \\
\hline
\end{tabular}

*Statistically significant at $\mathrm{p} \leq 0.05$

Table 4. Comparison between grade of nipple trauma pre and post intervention among two groups $(\mathrm{N}=116)$

\begin{tabular}{|c|c|c|c|c|c|c|}
\hline \multirow[t]{2}{*}{ Grade of nipple pain } & \multicolumn{2}{|c|}{$\begin{array}{c}\text { EVOO group } \\
(n=58)\end{array}$} & \multicolumn{2}{|c|}{$\begin{array}{c}\text { Control group } \\
(n=58)\end{array}$} & \multicolumn{2}{|c|}{ Chi square test } \\
\hline & No. & $\%$ & No. & $\%$ & $\mathbf{X}^{2}$ & $\mathbf{P}$ \\
\hline \multicolumn{7}{|c|}{ Pre intervention } \\
\hline \multicolumn{7}{|l|}{ First day of enrollment } \\
\hline Erythema and/or edema & 9 & 15.5 & 10 & 17.2 & & \\
\hline Superficial damage $<25 \%$ & 27 & 46.6 & 28 & 48.3 & & \\
\hline Superficial damage $>25 \%$ & 22 & 37.9 & 20 & 34.5 & 0.166 & 0.920 \\
\hline \multicolumn{7}{|c|}{ Post intervention } \\
\hline \multicolumn{7}{|l|}{ Seventh day } \\
\hline No skin change & 30 & 51.7 & 18 & 31.0 & & \\
\hline Erythema and/or edema & 17 & 29.3 & 16 & 27.6 & & \\
\hline Superficial damage $<25 \%$ & 7 & 12.1 & 14 & 24.1 & & \\
\hline Superficial damage $>25 \%$ & 4 & 6.9 & 10 & 17.2 & 7.935 & $0.047 *$ \\
\hline \multicolumn{7}{|l|}{ Fourteenth day } \\
\hline No skin change & 52 & 89.7 & 37 & 63.8 & & \\
\hline Erythema and/or edema & 5 & 8.6 & 9 & 15.5 & & \\
\hline Superficial damage $<25 \%$ & 0 & 0.0 & 7 & 12.1 & & \\
\hline Superficial damage $>25 \%$ & 1 & 1.7 & 5 & 8.6 & 13.338 & $0.004 *$ \\
\hline
\end{tabular}

*Statistically significant at $p \leq 0.05$ 


\section{Discussion:}

The present study aimed to evaluate the effect of extra virgin olive oil on nipple trauma among lactating mothers. The hypothesis was achieved through the present study findings which revealed that, lactating mothers who utilized extra virgin olive oil exhibited faster recovery of nipple trauma than the control group.

The present study revealed that, nipple trauma scores had significantly decreased after intervention in the EVOO group compared to the control group. This study finding may be due to that, the olive oil has good antioxidant properties and natural phenolic compounds and considered as a natural inhibitor that improves blood flow to the tissue, reduces inflammation and reduces cell damage because lipid profile of olive oil is very similar to that of human skin. Additionally, oleocanthal compound which founded in olive oil is homologous with the non-steroidal anti-inflammatory drug (NSAID) leading to alleviate the inflammatory process; this may speed up wound healing and recovery process.

Such finding agree with Gungor et al. (2013) ${ }^{(23)}$ who conducted the study on 31 lactating mothers and focused on the beneficial effect of olive oil in the prevention of sore nipples, reported that, the olive oil is a preferable dressing for nipples to protect from cracking during suckling, especially in early lactation.

Also, the present study finding go in the same line with an experimental, prospective, randomized study of 300 lactating mothers conducted in Cienfuegos, Cuba at postpartum unit of the city's general hospital by Cordero, Villar, Barrilao, Corte's and Lo' pez, (2015) ${ }^{(8)}$ who compared the application of EVOO versus breast milk on prevention of cracked nipple, they concluded that, EVOO had significantly manage the cracked nipple than the other group. So, the authors suggested that, application of few drops of EVOO on the nipple after breastfeeding provided substantial protection against the occurrence of cracked nipple.

Additionally, the study finding supported by Cort'es Castell et al. (2014) (24) who conducted study to investigate the anti-inflammatory activity of a polyphenolic extract from olive pits on 80,000 cells which was incubated and exposed to $0.1 \mathrm{mg} / \mathrm{ml}$ of LPS (lipopolysaccharide from E. coli) for 24 hours to be inflamed. The authors observed that, the olive oil has beneficial effects on prevention and treatment of inflammation.

The present study showed that, on the seventh day post interventions slightly more than half of EVOO group had normal skin without any skin change compared to less than one third of the control group who had normal nipple skin. This study finding come in accordance with Kirlek and Akdolun- Balkaya, $(2013)^{(25)}$ who conducted an experimental study aimed to compare the effects of olive oil and breast milk on prevention of cracked nipple in early puerperium period on 39 lactating

mothers; 13 mothers each in breast milk, olive oil, or control groups. The findings showed that, there was statistically significant difference between study group who utilize olive oil and other groups in the occurrence of cracked nipple in their first week post intervention.

The present study noted that, on the fourteenth day after intervention most mothers in the study group had normal nipple skin compared to less than two thirds of mothers in the control group who had normal nipple skin changes.

This study finding was in

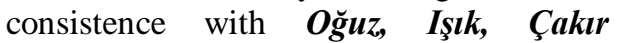
Güngör, Şeker, and Ogretmen, (2014) ${ }^{(9)}$ who conducted study aimed to evaluate the 
OLIVE OIL ON NIPPLE TRAUMA AMONG etc...

effectiveness of olive oil on protection of nipples from soreness on 56 women. In which the authors asked mothers tried two kinds of products at the same time: lanolin on one nipple and EVOO on the other to have the chance to compare the exact efficacy of both products and eliminated the individual factors that might affect wound healing. They indicated that, after 15 days of intervention there were statistically significant difference between two groups; mostly of the mothers were more satisfied with topical use of EVOO than other group.

On the other hand, a clinical trial which conducted by Eshgizade, Moghaddam, Moghaddam, Mahmoudian, and Mina, (2016) $)^{(26)}$ on 90 lactating mothers with breast fissure in Gonabad city to compare the effect of olive oil, aloe vera extract, and breast milk on breast fissure, founded that, aloe vera extract is the most effective method for the management of breast fissure. The discrepancies may be due to use different type of olive oil.

Also, in a comparative intervention study in Egypt, by Ahmed, Mohamed, and Abu-talib, $(2015)^{(27)}$ to assess the effect of evidence based guidelines for alleviating traumatic nipple among 150 nursing mothers in the postnatal Maternity Unit and outpatient family planning clinic at Ain Shams University Maternity Hospital. The authors concluded that, there was no statistically significant difference between groups who applied routine methods for medical management of nipple trauma or who applied the most evidence alternative management either on seventh or fourteenth day post interventions.

Other studies $(28$ \&29) examined the effect of olive oil on the healing process of episiotomy wound, reported that olive oil was effective in improvement of healing of episiotomy wound on the $7^{\text {th }}$ and $14^{\text {th }}$ days and lower redness edema, ecchymosis, discharge and approximation on the $5^{\text {th }}$ and $10^{\text {th }}$ days than control group.

Additionally, the finding of the present study go in the same line with a quasi-experimental study conducted in Egypt, by Elshenawie, Shalan, and Abdelaziz, (2013) ${ }^{(30)}$ at Alexandria Main University Hospital, to measure the effect of ozonated olive oil ointment technique on the healing of superficial and deep diabetic foot ulcers on 30 adult patients who were divided into two equal groups, study and control groups. The study group was treated by ozonated olive oil ointment and control group was treated by hospital routine solutions. After 2 and 3 weeks during follow up the ozonated olive oil dressing had significant effect on wound healing than control group.

Similarly, in Iran, 2015 a doubleblind randomized clinical trial study was conducted on 34 patients with diabetic foot ulcers of Wagner's ulcer grade 1 or 2 and assigned randomly into two equal groups; study group received topical olive oil in addition to routine cares, whereas patients in control group just received routine cares. The authors reported that, olive oil in combination with routine cares is significantly more effective than routine cares alone without any side effect ${ }^{(31)}$.

\section{Conclusion}

Based on the findings of the present study, it can be concluded that, majority of lactating mothers who used extra virgin olive oil (EVOO) had faster recovery of nipple trauma on the seventh and fourteenth day post intervention more than lactating mothers in control group.

\section{Recommendations}

Based on the findings of the present study, the following recommendations were suggested:

1. Raising lactating mothers' awareness regarding the beneficial effect of olive oil on nipple trauma and how to apply it through a brochure or a booklet. 
Haylaa Nageeb et. al.

2. Raising awareness of health care providers regarding olive oil and its effect on nipple trauma.

Further Studies: Apply further researches to

1. Evaluate the effect of olive oil on prevention of nipple trauma.

2. Assess the relationship between antenatal classes for prevention of nipple trauma and incidence of nipple trauma.

\section{References}

1. Williamson, I., Leeming, D., Lyttle, S., \& Johnson, S. (2012). 'It should be the most natural thing in the world': exploring first-time mothers' breastfeeding difficulties in the UK using audio-diaries and interviews. Matern Child Nutr., 8(4), 434-447.

2. Al Ghwass, M., \& Ahmed, D. (2011). Prevalence and Predictors of 6-Month Exclusive Breastfeeding in a Rural Area in Egypt. Breastfeeding medicine, 6(4), 191-196. Retrieved from:

http://online.liebertpub.com/doi/pdf/1 $\underline{0.1089 / \mathrm{bfm} .2011 .0035}$

3. Shimoda, G., Soares, A., Aragaki, I., \& Mcarthur, A. (2015). Preventing nipple trauma in lactating women in the University Hospital of the University of Sao Paulo: a best practice implementation project. $J B I$ Database System Rev. Implement Rep., 12 (13), 212-32.

4. Cervellini, M., Gamba, M., Coca, K., \& Abrão A. (2014). Injuries resulted from breastfeeding: a new approach to a known problem. Rev Esc Enferm USP, 48(2), 340-350.

5. Thompson, R., Kruske, S., Barclay, L., Linden, K., Gao, Y., \& Kildea, S. (2016). Potential predictors of nipple trauma from an in-home breastfeeding programme: a crosssectional study. Women Birth, 29 (4), 336-44.
6. Akbari, S., Alamolhoda, S., Baghban, A., \& Mirabi, P. (2014). Effects of menthol essence and breast milk on the improvement of nipple fissures in breastfeeding women. $J$ Res Med Sci., 19(7), 629-33.

7. Allen, K., (2014). A Randomized Controlled Trial Evaluating Lanolin for the Treatment of Nipple Pain among Breastfeeding Women; Published thesis Graduate Department of Nursing Science, University of Toronto.

8. Cordero, M. J., Villar, N. M., Barrilao, R. G., Corte' s, M. E., \& Lo' pez, A. M. (2015). Application of Extra Virgin Olive Oil to Prevent Nipple Cracking in Lactating Women. Sigma Theta Tau International, Worldviews on Evidence-Based Nursing, 12(6), 364 369.

9. Oğuz, S., Işık, S., Çakır Güngör, A.N., Şeker, M., \& Ogretmen, Z., (2014). Protective Efficacy of Olive Oil for Sore Nipples during Nursing. $J$ Family Med Community Health, 1(4): 1021-1024.

10. Echolls, T., (2017). What Do Olives Represent in Islam? Classroom, Leaf Group Education. Retrieved from https://classroom.synonym.com/what -do-olives-represent-in-islam12087654.html

11. Olive oil source (2017). History of olive oil. Retrieved from: https://www.oliveoilsource.com/page /history-olive. Retrieved August 2017

12. Al Najjar, Z., (2015). Wonders of the Ever-Glorious Qur'an. Miraculous signs in the Noble Qur'an and their scientific implications. (pp. 21). Daraltarjama, com. Retrieved from:

https://docslide.com.br/download/lin k/dr-zaghloul-an-najjar-miracles-inthe-quran-a-book-com 
OLIVE OIL ON NIPPLE TRAUMA AMONG etc...

13. El- Naggar, Z., (2018). The Fig, the Olive and Mount Sinai. Retrieved from http://www.elnaggarzr.com/en/main. php?id=45\&Shift $=1$

14. Ganceviciene, R., Liakou, A., Theodoridis, A., Makrantonaki, E., \& Zouboulis, C., (2012). Skin antiaging strategies. Dermatoendocrinol, 4(3), 308-319. doi: 10.4161/derm. 22804.

15. D'Angelo, S., Ingrosso, D., Migliardi, V., Sorrentino, A., Donnarumma, G., Baroni, A., Masella, L., Antonietta Tufano, M., Zappia, M., \& Galletti, P. (2005). Hydroxytyrosol, a natural antioxidant from olive oil, prevents protein damage induced by long-wave ultraviolet radiation in melanoma cells. Free Radic Biol Med., 38(7), 908-919.

16. Dening, J., (2016). Olive Oil and Infection. Olive oil times, Filed in Health. Retrieved from. https://www.oliveoiltimes.com/oliveoil-health-news/olive-oil-andinfection/51057

17. Buck, M., Amir, L., Cullinane, M., \& Donath, S. (2014). Nipple Pain, Damage, and Vasospasm in the First 8 Weeks Postpartum. Breastfeed Med, 9(2), 56-62.

18. Dias, J., Vieira, T., \& Vieira, G. (2017). Factors associated to nipple trauma in lactation period: a systematic review. Rev. Bras. Saúde Matern. Infant. Recife, 17 (1), 27-42.

19. Kent, J., Ashton, E., Hardwick, C., Rowan, M., Chia, E., Fairclough, K., Menon, L., Scott, C., MatherMcCaw, G., Navarro, K., \& Geddes, D. (2015). Nipple Pain in Breastfeeding Mothers: Incidence, Causes and Treatments. Int. J. Environ. Res. Public Health, 12(10), 12247-12263.
20. McClellan, H., Hepworth, A., Garbin, C., Rowan, M., Deacon, J., Hartmann, P., \& Geddes, D. (2012). Nipple pain during breastfeeding with or without visible trauma. J. Hum. Lact., 28(4), 511521.

21. Abou-Dakn, M., Fluhr, J.W., Gensch M., \& Wöckel, A. (2011). Positive Effect of HPA lanolin versus expressed breast milk on painful and damaged nipples during lactation. Skin Pharmacol Physiol., 24(1), 2735.

22. International Olive Council (IOC), (2015). Trade Standard Applying to Olive Oils and Olive-Pomace Oils COI/T.15/NC, No3/Rev. 8 Pp1-17. Retrieved from: http://www.internationaloliveoil.org/ documents/viewfile/3615-normaen1

23. Gungor, A., Oguz, S., Vurur, G., Gencer, M., Uysal, A., Hacivelioglu, S., Uludag, A., and Cosar, E. (2013). Comparison of Olive Oil and Lanolin in the Prevention of Sore Nipples in Nursing Mothers. Breastfeeding Medicine, 8(3), 334-335.

24. Cortés-Castell, E., Galindo, C., Montell, L., Segura E., Baeza, M., \& Guillén, V. (2014). Antiinflammatory activity of olive seed polyphenolic extract in the thp1xblue-cd14 human monocytes cell line. Nutr Hosp, 30(1), 113-117.

25. Kirlek, F., \& Akdolun-Balkaya, N. (2013). The effects of breast milk and olive oil on prevention of nipple pain and nipple cracks at early postpartum period. Hemşirelikte Araştırma Geliştirme Dergisi, 15(2): 17-34.

26. Eshgizade, M., Moghaddam, M.B., Moghaddam, H.M., Mahmoudian, A., \& Mina, M. (2016). Comparison of the Effect of Olive Oil, Aloe Vera Extract and Breast Milk on Healing of Breast Fissure in Lactating 
Haylaa Nageeb et. al.

Mothers: A Randomized Clinical Trial. Qom Univ Med Sci J, 10(3), 1927.

27. Ahmed, E., Mohamed, H., \& Abutalib, Y. (2015). Evidence Based Guideline Using to Alleviate Traumatic Nipple among Nursing Mothers. World Journal of Nursing Sciences, 1 (3), 35-44.

28. Behmanesh, F., Aghamohammadi, A., Zeinalzadeh, M., \& Khafri, S. (2013). Effects of olive oil sitz bath on the improvement of perineal injury after delivery. Koomesh, 14(3), 309-315.

29. Kaviani, M., Sepasi, S., Azima, S., Emamghoreishi, M., Asadi, N., \& Haghpanah, S. (2017). The effects of olive leaf extract ointment on pain intensity and early maternal complications in primiparous women. Int J Pharm Pharm Sci, 9(7), 31-34.
30. Elshenawie, H.A., Shalan, W.E., Abdelaziz, A.E. (2013). Effect of Ozone Olive Oil Ointment Dressing Technique on the Healing of Superficial and Deep Diabetic Foot Ulcers. J Am Sci., 9(11), 235-50.

31. Nasiri, M., Fayazi, S., Jahani, S., Yazdanpanah, L.,

\& Haghighizadeh, M. (2015). The effect of topical olive oil on the healing of foot ulcer in patients with type 2diabetes: a double-blind randomized clinical trial study in Iran. Journal of Diabetes \& Metabolic Disorders, 14(1), 38. 